\title{
Bergson ja intuitio filosofian metodina
}

\author{
KATARIINA LIPSANEN
}

VERTAISARVIOITU
KOLLEGIALT GRANSKAD
PEER-REVIEWED
www.tsv,ti/tunnus

\begin{abstract}
ABSTRAKTı Tässä artikkelissa käsittelen Henri Bergsonin (1859-1941) intuition käsitettä ja sen suhdetta hänen filosofiseen menetelmäänsä. Bergsonin on nähty tarkoittavan intuitiolla yhtäältä filosofian metodia ja toisaalta tiettyä älyyn verrattavaa filosofialle ainutlaatuista tiedon muotoa. Esitän, että Bergsonille intuitio on samanaikaisesti näitä molempia. Se on todellisuuden ajattelemista kestona, sisäistä jatkuvuuttamme muistuttavana liikkeenä. Intuitiossa tavoitetaan todellisuuden luonne sikäli kuin se on läsnä myös meissä itsessämme tällaisena jatkuvuutena. Metodologisesti se on todellisuuden tarkastelua ajallisuuden ja muutoksen perspektiivistä. Tiedon muotona se on välitöntä ymmärrystä tarkastelun kohteesta itsestään.
\end{abstract}

\section{Johdanto}

Teoksessaan La pensée et le mouvant (Ajattelu ja liike, 1938) Henri Bergson toteaa päätyneensä "tekemään intuitiosta filosofisen metodin" (Bergson 2013/1934, 25). Yleisesti filosofiassa intuitio mielletään välittömäksi käsittämiseksi, johon ei liity päättelyä eikä järkeilyä. Metodi puolestaan käsitetään yleisesti menettelytapana, tiedon hankkimisen keinona. Näitä käsityksiä vasten herääkin kysymys, mitä Bergson intuition metodillaan oikein tarkoittaa. "Välitön käsittäminen" vaikuttaa pikemminkin ymmärrykseltä, joka saavutetaan, eikä niinkään itse ymmärryksen saavuttamisen keinolta. Bergsonin metodin analysoimisesta haasteellista tekee se, ettei hän koskaan tehnyt siitä systemaattista ja tyhjentävää esitystä. Metodista on löydettävissä lähinnä sivuhuomautuksia ja vertauskuvallisia ilmaisuja pitkin Bergsonin tuotantoa. Tässä artikkelissa käsittelen aihetta tar- kastelemalla Bergsonin intuition käsitettä hänen epistemologiansa näkökulmasta ja arvioimalla käsitteen menetelmällisiä piirteitä. Tavoitteenani on antaa koherentti esitys intuition käsitteen suhteesta Bergsonin filosofiseen menetelmään.

Bergson filosofian on katsottu kytkeytyvän ranskalaisen 1800-luvun spiritualistisen filosofian jatkumoon, jonka muita tärkeitä edustajia olivat esimerkiksi Felix Ravaisson (1813-1900) ja Victor Cousin (1792-1867). Näistä Felix Ravaisson oli Bergsonin opettaja ja edusti niin sanottua "spiritualistista positivismia". Spiritualismin lisäksi Ranskassa merkittävänä uutena suuntauksena oli Auguste Comten ja Hippolyte Tainen edustama positivismi. Bergsonin opiskeluaikoina Pariisin École Normale Supérieure oli filosofisesti jakatunut kahtia uuskantilaisiin ja positivisti Herbert Spencerin filosofian seuraajiin. Bergson itse lukeutui Spencerin filosofian kannattajiin ja oli ai- 
keissa suuntautua tieteenfilosofiaan Spenceristä vaikuttuneella otteella. (Verdeau 2007, 361-362.) Ranskalaisen filosofian tälle kaudelle on nähty leimallisena pyrkimys ilmiöiden taustalla olevien järjellä tavoitettavia varmojen ja pysyvien totuuksia tavoittelu, mikä näyttäytyi erilaisten lakien, säännönmukaisuuksien ja prinsiippien etsimisenä (Bréhier 1973, 119-120). Juuri tätä filosofiaa vastaan Bergson asettuu erityisesti myöhäisemmässä ajattelussaan.

Väitöskirjaa tehdessään Bergson kuitenkin ensimmäisenä havahtui tieteiden ja positivististen ajattelijoiden, kuten Herbert Spencerin, filosofisten järjestelmien taustalla olevaan käsitykseen ajasta, joka hänen mukaansa oli problemaattinen ja kaukana ajan todellisesta luonteesta (Verdeau 2007, 361-362). Myöhemmin filosofiassaan Bergson tuo esille, ettei kyse ole vain ajasta vaan muutoksesta yleensä. Teoksessa L'Évolution créatrice Bergson esittää, kuinka filosofia läpi sen historian Platonista ja Aristoteleesta aina Kantiin asti on suorastaan pyrkinyt eroon todellisesta muutoksesta (ks. Bergson 2013/1907, 313-369). Bergson esittää, että todellisen muutoksen ymmärtäminen on filosofian tehtävä, ja intuitio näyttää keinolta sen tavoittamiseen (Bergson 2013/1934, 140-141; 2013/1907, 367-369).

Bergson-tutkijoiden parissa esiintyy jonkin verran keskustelua Bergsonin "intuition" ja "metodin" käsitteiden välisestä suhteesta. Keskustelu siitä, missä mielessä Bergsonin väite intuitiosta filosofisena metodina tulisi ymmärtää, on kuitenkin vielä hyvin avoin. Laajempia esityksiä Bergsonin metodista ovat tehneet esimerkiksi Jacques Chevalier (1928), Gilles Deleuze (1966) ja Camille Riquier (2009). Bergsonin filosofian skolaarissa tutkimuksessa, esimerkiksi juuri Chevalierin esityksessä on erityisesti kiinnitetty huomiota siihen, minkälaiseen tiedon muotoon intuitio liittyy; oikeastaan tulee vaikutelma, että intuitiossa on kyse pikemminkin erityisestä tiedon muodosta kuin metodista. Tämä näyttää perustellulta siksi, että Bergson usein käsittelee intuitiota kuin se olisi rinnastettavissa älyyn tai älykkyyteen (intelligence). Puhuessaan intuitiosta Bergson usein painottaa, minkälaisesta tiedosta filosofiassa on kyse, ja miten se eroaa esimerkiksi tieteellisestä tiedosta. Bergsonin intuition käsitteen onkin nykytutkimuksessa tulkittu esimerkiksi tarkoittavan filosofian ainutlaatuista tiedon muotoa, jonka saavuttamiseksi filosofian on kehitettävä tietynlainen metodi. Camille Riquierin mukaan intuitio onkin Bergsonin filosofisen metodin päämäärä, joka voidaan erottaa itse metodista (Riquier 2009, 133).

Eriasteisia metodologisia tulkintoja löytyy jonkin verran. Ehkä vaikutusvaltaisimman tulkinnan Bergsonin intuition käsitteestä on tehnyt filosofi Gilles Deleuze (1925-1995). Deleuzen mukaan Bergsonin intuitio on filosofinen metodi, ja hän tulkitsee sen muodostuvan tarkoista säännöistä, jotka hän nimeää teoksessaan Bergsonismi (Le bergsonisme; Deleuze 2011/1966, 1-31). Deleuzen esityksen ilmeisenä puutteena kuitenkin on, ettei hän puhu itse intuitiosta metodia käsittelevässä luvussa parin ensimmäisen sivun jälkeen. ${ }^{1}$ Arnaud François puolestaan on esittänyt intuition olevan Bergsonille metodi, sillä se ei voi hänen mukaansa olla tuloksistaan erillinen mielenkyky (Bouanice ym. 2013, 322, alaviite 1). Dimitri Tellier taas korostaa intuition iteratiivista luonnetta; sillä ei ole määrättyjä sääntöjä, vaan se on pikemminkin kuin reitti, metodi kohti metafyysisiä totuuksia (Tellier 2012, 40).

Henri Hude on tarkastellut Bergsonin intuitiota keksimisen ja luomisen näkökulmasta ja kuvailee metodia "välittömän keksimisen metodiksi" (méthode d'invention de l'immédiat), jossa intuitio on osa tätä prosessia (Hude 2008, 187). Yksi tulkintatapa on myös ollut käsittää intuitio Bergsonin filosofisen metodin yhdeksi vaiheeksi (Riquier 2009, 134). Vielä viimeisenä mainittakoon eräs tärkeä kontribuutio intuition ja metodin käsittelyyn: David Lapoujade esittää, että intuition metodologisuus löytyy sen erosta suhteessa vaiston käsitteeseen (Lapoujade 2008). Lapoujade on myös esittänyt, että intuition metodin ytimessä on ainutlaatuinen vaistoon kytkeytyvä analogiapäättelyn idea (ks. esim. Lapoujade 2008, 17; 2010, 59-60). Aikaisemman tutkimuksen perusteella näyttää siis siltä, että intuition voidaan nähdä olevan Bergsonille joko 1) itse filosofinen metodi, 2) osa filosofista metodia tai 3) filosofisen metodin päämäärä. 
Tässä artikkelissa vastaan näiden tutkimusten kautta ilmenneeseen epäselvyyteen intuition roolista suhteessa filosofian menetelmään. Esitän, että intuitio Bergsonilla voidaan käsittää sekä filosofian metodina että filosofisena tiedon muotona, ja että intuition roolin epäselvyys liittyy sen tietynlaiseen kaksoistehtävään. Intuitio on ensisijaisesti filosofisen työskentelyn päämäärä eli jonkin asian välitöntä käsittämistä, muodoltaan filosofialle erityisen tiedon saavuttamista. Intuitio ei ole kuitenkaan läsnä vasta filosofisen työskentelyn lopussa vaan se ohjaa filosofin työtä sen jokaisessa vaiheessa. Se toimii ikään kuin vielä jäsentymättömänä näkemyksenä, joka suuntaa filosofista tutkimusta. Lopulta saavutetaan välitön ymmärrys asian luonteesta intuitiivisen näkemyksen tarkentuessa.

Tämän artikkelin ensimmäisessä osiossa tarkastelen Bergsonin käsitystä filosofian luonteesta, jota havainnollistetaan peilaamalla filosofiaa tieteeseen. Tarkoituksenani on tuoda esiin intuition epistemologisia päämääriä, joiden pohjalta voidaan tarkastella käsitteen roolia suhteessa filosofiseen tiedon muotoon ja menetelmään. Toisessa osassa käsittelen Bergsonin tulkintaa inhimillisten tiedonkykyjen alkuperästä eli siitä, millaisesta tiedon muodosta intuitiossa on kysymys. Osiossa tuon esille näkökulmia, jotka tuovat esille intuition luonteen mentelmästä erotettavana tai siihen kytkeytyvänä tiedon muotona. Kolmannessa osiossa taas tuon esille selkeämmin metodologista näkökulmaa ja tarkastelen Bergsonin luonnehdintoja filosofian metodista ja intuition roolia suhteessa siihen. Lopuksi hahmottelen, miten intuitio voidaan ymmärtää näiden huomioiden valossa sekä filosofisena tiedon muotona että metodina.

\section{Filosofisen tiedon luonne ja intuition päämäärä}

Intuition kannalta on asianmukaista tarkastella Bergsonin käsitystä filosofisen tiedon suhteesta tieteelliseen tietoon. Bergson esittää filosofian tutkimuskohteen ja filosofisen tiedon luonteen yleensä juuri erottaen sen tieteestä. Lisäksi Bergson katsoo filosofien usein tekevän filosofiaa tie- teen keinoin ja haluaa siksi teroittaa, millä tavalla filosofian tutkimuskohde on sille ainutlaatuinen ja vaatii oman tiedon muodon ja metodin. Tieteen ja filosofian tehtävien ja tarkastelutapojen jaottelu ei ole missään määrin arvottava: filosofia ja tiede täydentävät toisiaan ja ovat kuin erikoistuneet erityyppisen tiedon tuottamiseen (Bergson 2013/1907, 200).

Tiede ja filosofia edustavat Bergsonille kahta erilaista kokemustyyppiä. Tieteellisen tiedon perustana on ulkoinen kokemus, ja tämä tieto on luonteeltaan suhteellista. Filosofia sen sijaan perustuu sisäiseen kokemukseen. Sen tavoittama tieto on suhteellisen sijaan absoluuttista (Bergson 2013/1934, 136-138). Tieteen suhteellista tietoa muodostetaan määrätystä tulokulmasta annetuilla symboleilla ja se saavutetaan analyysillä (Bergson 2013/1934, 177-178; 181). Filosofian absoluuttinen tieto ei tarkoita, että tieto olisi lopullista tai ikuista, vaan pikemminkin suoraa tietoa asiasta itsestään. Näiden välillä on selvä kontrasti; tieteen tieto on suhteellista, välillistä kun taas filosofian suoraa ja välitöntä. Esimerkkinä näiden kahden tiedon luonteesta Bergson mainitsee vieraan kielen ääntämyksen opiskelun. Kirjasta voidaan saada suhteellista tietoa esimerkiksi englannin kielen lausumisesta, kun sanojen lausunta on avattu opiskelijan äidinkielellä. Saamme tietoa lausunnasta suhteessa äidinkieleemme ja opimme kieltä sen kautta. Absoluuttista tietoa muistuttaa taas se, jos opiskelija menisi elämään englantia puhuvien keskuuteen ja oppisi lausunnan sisältä käsin elämällä kyseisessä kielessä. (Bergson 2002, 26-27.)

Tieteen ja filosofian tarkastelussa esille nousevat yhtäältä niiden tuottamien tiedon luonteiden erot, mutta myös niiden yhteneväisyys. Bergsonille molemmat ovat progressiivisia, itseään korjaavia: filosofia erityisesti sen spekulatiivisen luonteen vuoksi (Bergson 1959, 31; 61). Bergsonin käsityksen mukaan niiden tuottama erilainen tieto on toisiaan täydentävää. Ajatuksena on, että filosofia ja tiede tavoittavat todellisuuden sen kahden eri luonteen kautta ja sikäli voimme niiden yhteistyöllä saada kokonaiskäsityksen todellisuudesta.

Tieteen tarkastelutapa kumpuaa itse ihmi- 
sälyn luonteesta ja Bergsonin mukaan se on ihmisen totunnainen tapa tarkastella todellisuutta (Bergson 2013/1907, 29; 196). Tämän vuoksi ihmiset eivät Bergsonin mukaan muutosta tarkastellessaan usein osaa erottaa toisistaan välitöntä muutoksen kokemusta ja ihmisälyn muodostamaa miellettä koetusta muutoksesta. Välitön kokemus jää oikeastaan huomiotta ja ihmisälyn jo analysoima ja jäsentämä kokemus käsitetään välittömäksi kokemukseksi. Tämän vuoksi havaittu laadullinen muutos ymmärretään usein määrälliseksi. (Bergson 2013/1889, 38.) Teoksessa Essai sur les données immédiates de la conscience (Tutkielma tietoisuuden välittömistä sisällöistä, 1889) Bergson esittää useita tapauksia, joissa tulkitsemme välittömän kokemuksemme jostain laadullisesta muutoksesta juuri tällä tavoin: kokemus äänen voimakkuuden tai korkeuden muutoksesta jäsennetään mitattavaan muotoon eli värähtelyksi, vaikka aistimamme muutokset ilmenevät meille laadullisesti (Bergson 2013/1889, 33-34). Äänen voimakkuutta tai korkeutta voidaan tietenkin mitata tai esittää esimerkiksi sävelasteikolla ja tällaisella jäsennyksellä on oma tehtävänsä. Se ei kuitenkaan tavoita muutosta, joka välittyy meille äänen kokemuksessa. Bergson luonnehtii tätä ihmisajattelun taipumusta jäsentää muutosta "ajattelun elokuvalliseksi mekanismiksi" (mécanisme cinématographique de la pensée; ks. Bergson 2013/1907, 313-314). Mekanismissa on kyse siitä, että alkuperäinen liike pysäytetään ja jaetaan osiin, kuin yksittäisiksi kuviksi filmillä. Liike ja muutos rekonstruoidaan keinotekoisesti pyörittämällä filmiä, jolloin yksittäisten kuvien nopea peräkkäisyys antaa illuusion liikkeestä. Todellisuudessa näitä liikkeen erillisiä vaiheita ei ole olemassa. Sellaisia voidaan keinotekoisesti rajata, mutta liike ja muutos ei muodostu niistä. Todellisuudessa kuvauksen kohteena oleva liike on yhtä jatkumoa ilman vaiheita. Ihmisajattelulla on vain luontainen tapa käsittää muutosta tällaisen rekonstruktion kautta. (Bergson 2013/1907, 305-306.)

Bergsonin mukaan filosofian tulee ajatella ja ymmärtää asiat sub specie durationis - keston, eli ajallisuuden näkökulmasta (Bergson 2013/1907, 30; 142; 176). Bergson omaksuu tässä Spinozan ilmaukseen sub specie aeternitatis ${ }^{2}$ - ikuisuuden näkökulmasta - ja muuttaessaan sitä erottautuu filosofian historiassa näkemästään ikuisuuden ideaalista, jonka mukaan löytääkseen totuuden filosofien on päästävä ajallisuuden tuolle puolen. Filosofian tavoitteena on tässä perinteisessä ideaalissa löytää ikuisia, todellisuutta määrittäviä perimmäisiä prinsiippejä, lakeja tai käsitteitä. Bergsonin mukaan tällainen ihanne määrää filosofian tehtäväksi käsitejärjestelmien luomisen ja niiden sisäisen logiikan selvittämisen. Bergsonin mukaan suuret käsitteet kuten substanssi, minä, idea tai tahto väistämättä synnyttävät järjestelmän ja ikään kuin sanelevat, miten asiat on nähtävä, mikäli sitoudumme näihin käsitteisiin. (Bergson 2013/1934, 26.) Bergsonin kritiikki näyttää olevan, että kun haemme ikuisia kaikkea määrittäviä käsitteitä, voimme hylätä todellisuuden, kun ylin prinsiippi tai käsite on määritelty. On tulkittu, että Bergson ajattelee abstraktista ideoiden ja muotojen käsitejärjestelmästä tulevan filosofialle todellisempi kuin itse havaittava todellisuus (François 2010, 56). Todellisuuden on nimittäin mukauduttava käsitejärjestelmän ehtoihin, jotta järjestelmä säilyy koherenttina. Mutta eikö todellisuuden tutkimisessa asian pitäisi olla toisin päin? Eikö käsitteiden tulisi mukautua todellisuuden omaan tapaan jäsentyä?

Bergsonin tavoitteena on löytää keino tarkastella todellisuutta sen omilla ehdoilla, sen omasta luonteesta käsin (Bergson 2013/1934, 23; 51). ${ }^{\mathrm{a}}$ Sen sijaan, että pyristelisimme aikaa ja muutosta vastaan ja tavoittelisimme jotain ikuista, meidän tulisi tarkastella sitä, mitä voimme löytää oman ajallisen luonteemme kautta. Filosofian tulisi Bergsonin mukaan tarkastella maailmaa jatkuvasti muuttuvana itse muutoksesta käsin eikä yrittää vangita tätä muutosta symbolisella tiedolla, jonka toimintaperiaatteeseen kuuluu muuttumattomuus. Tieteen tavoin filosofian tulisi luopua lopullisuuden tavoittelusta. Bergsonin ideaalissa filosofia on tieteen tapaan progressiivinen, asteittain kehittyvä ja itseään korjaava tutkimusala (Bergson 1959, 61).

Voidaan oikeutetusti kysyä, pystyykö Bergson ylittämään näitä filosofian haasteita ja kykeneekö hän todella tarkastelemaan todellisuutta sen 
omilla ehdoilla. Mitä enemmän Bergsonin filosofiaan syvennytään, sitä selvemmäksi muodostuu käsitys, että Bergsonin ajattelussa on tietty ontologinen oletus, joka on allekirjoitettava, jotta hänen filosofinen metodinsa on käsitettävissä ja siten sovellettavissa. Pääpiirteissään tässä järjestelmässä todellisuus käsitetään tietyssä mielessä dualistisena. Todellisuus on liikettä ja muutosta, joka muodostuu kahden vastakkaisen liikkeen välisestä tasapainottelusta: aineesta (matière) ja hengestä (esprit). Tämä dualismi heijastuu Bergsonin ajattelussa myös tieteen ja filosofian työnjaossa. Tiede tarkastelee todellisuutta aineen näkökulmasta ja filosofia hengen näkökulmasta. (Bergson 1972, 887.) Käytännössä tämä tarkoittaa sitä, että tiede analysoi todellisuudessa kaikkea ikään kuin se olisi tilallista ja pysähtynyttä, kun filosofia puolestaan tarkastelee kaikkea liikkeenä ja muutoksena. Tietyssä mielessä siis tarkastelutapa on päinvastainen kuin filosofian perinteisissä käsityksissä. Aine ei olekaan ensisijaisesti muuttuva ja ajallinen; nämä ominaisuudet liittyvät ensisijaisesti ymmärrykseen hengestä. Tätä voidaan verrata esimerkiksi Aristoteleen hylemorfismiin, jossa filosofiaa erityisesti kiinnostaa ikuiset muodot ja aineellinen nähdään muuttuvana. ${ }^{3}$

Filosofiassa intuition ainutlaatuisuus näyttääkin perustuvan siihen, että sen avulla pääsemme käsiksi välittömään kokemukseen muutoksesta. Tässä välittömän kokemuksen tavoittamisessa keskeinen elementti on ajallisuus. Todellista aikaa - aikaa niin kuin sen välittömästi koemme - Bergson kutsuu kestoksi (durée). Kesto tavoitetaan ihmisen omana ajallisuutena, sisäisenä kestona, oman sisäisen kokemuksen jatkuvuutena. Bergsonille aika sellaisena kuin sen tavoitamme välittömän kokemuksen kautta ei ole määrällistä eikä mitattavaa. Keston kokemuksessa keskeistä on itse muutos ja siksi se edellyttää myös muistin olemassaoloa. Koemme ajan keston, koska mennyt kokemus on läsnä muistissamme ${ }^{4}$ ja nykyinen kokemus koetaan enemmän tai vähemmän erilaisena suhteessa siihen. (Bergson 2013/1889, 74-75.) Filosofinen tarkastelutapa sub specie $d u-$ rationis tarkastelee siis todellisuutta ja muutosta keston näkökulmasta. Intuition kautta tavoitamme muutoksen sellaisenaan, muutoksena.

\section{Intuitio filosofisen tiedon muotona}

Bergsonin mukaan tieteen tapa tarkastella todellisuutta on ihmiselle luontainen. Ihminen on kuitenkin hänen käsityksensä mukaan muiden eläinten tapaan kykeneväinen kahdentyyppiseen tietoon, ja filosofialle relevanttiin tiedon muotoon liittyy jotain ihmisajattelulle vähemmän totunnaista. Seuraavaksi käsittelen Bergsonin ajatusta näiden tiedon muotojen alkuperästä. Näiden pohjalta voidaan jäsentää, millaista tietoa nimenomaisesti intuitioon liittyy ja kuinka sitä voidaan saavuttaa.

Bergsonin syvällisin esitys inhimillisen tiedon alkuperästä löytyy teoksesta L'évolution créatrice (Luova evoluutio, 1907), jossa hän tarkastelee elämän kehityslinjaa kohti ihmistä. Bergson esittelee eläinkunnan kaksi tietoon liittyvää taipumusta: vaiston (instinct) ja älyn (intelligence). Bergsonin ajatuksena on, että kaikilla eläimillä on sekä vaistoon että älyyn pohjautuvaa tietoa, mutta kukin laji erikoistuu tietyllä tavalla painottamaan niistä toista. Ihminen eroaa muusta eläinkunnasta siinä, että ihminen on erittäin vahvasti ja poikkeavalla tavalla erikoistunut juuri älyyn. (Bergson 2013/1907, 135-136.) Tiedon muotona äly on väistämättä tietoista. Tietoisuus tarkoittaa kykyä tehdä valintoja ja päätöksiä, sillä älyä tarvitaan vain, kun ratkaisu ei ole automaattinen tai ilmeinen ja vaatii harkintaa. (Bergson 2013/1907, 144-146.) Äly on nimenomaisesti toimintaan suuntautuvaa tietoa (Bergson 2013/1907, 153). Vaistoon pohjautuva toiminta on puolestaan automaattista ja sikäli tiedostamatonta (Bergson 2013/1907, 144); hetkeäkään miettimättä kavahdamme ja hypähdämme kauemmaksi autosta, joka yhtäkkiä ilmestyy kadunkulmasta tielle, jonka olimme aikeissa ylittää. Älyä tarvitaan tilanteissa, joissa ratkaisu ei ole ilmeinen: ehdinkö ylittää tien ennen kuin kauempana näkyvä auto ehtii risteykseen? Tässä mielessä älyn tieto on pohdittua ja harkittua, vaiston taas toimittua ja koettua.

Bergsonin mukaan älyn ensisijaisena päämääränä on rakentaminen ja tuottaminen. Tätä se tekee vain liikkumattoman ja muuttumattoman aineen avulla, vaikka kyse ei olisi aineellisesta asiasta; se siis kohtelee kaikkea kuin 
se olisi pysähtynyttä ainetta. (Bergson 2013/1907, 154.) Tätä tuottamista havainnollistaa älyn kyvykkyys valmistaa välineitä tai työkaluja. Erityisesti ihmisellä on älyyn liittyvä kyky nähdä saavutettavissa olevissa havaintokohteissa välineiden valmistamiseen käytettäviä materiaaleja (Bergson 2013/1907, 140-142). Tämä johtuu siitä, että se tarkastelee kaikkea ikään kuin yhdestä ja samasta homogeenisesta substanssista eri suhteissa muodostuvina kokonaisuuksina. Äly näkee kaiken kuin kankaana, josta voidaan leikata tarvittavia määriä ja muotoja ja sommitella ne käyttötarkoitukseen sopivaksi. (Bergson 2013/1907, 157.) Esimerkiksi mikä tahansa pitkä esine on soveltuva väline puun oksien ravisteluun, kun leija on tarttunut niihin. Älyn avulla näemme siis tarkastelumme kohteissa pikemminkin niiden mahdollisia toimintoja kuin sen, mitä ne todella ovat. Ymmärryksemme tällaisista välineistä on täysin konstruoitua tai opittua. Jollekin esineelle nimetään tietty tarkoitus, oli funktio sitten hetkellinen tai pidempiaikainen. Tämä annettu tarkoitus ei ole siis esineelle ominainen tai perimmäinen, eikä älyn siksi tarvitse ymmärtää kohdetta ja sen luonnetta kovinkaan syvällisesti. Sille riittää ymmärrys siitä, miten kukin esine on suhteessa muihin esineisiin.

Vaistokin käyttää välineitä, mutta kyse on hyvin erilaisista välineistä. Se ei kykene antamaan uutta tai hetkellistä tarkoitusta millekään esineelle. Se käyttää ainoastaan sellaisia välineitä, joita sillä on synnynnäisesti käytettävissään ja jotka ovat osa sen ruumista. Tällaisia välineitä vastaa tietty vaisto, synnynnäinen ymmärrys niiden käytöstä. Toisin kuin äly, vaisto ei kykene rakentamaan mitään, vaan sen väline on lähtökohtaisesti valmis ja sen käyttötarkoitus on annettu. (Bergson 2013/1907, 140.) Esimerkkinä vaistomaisesta välineestä Bergson mainitsee pistiäisen piikin, jonka käyttötarkoitus on pistiäiselle synnynnäinen. Sen ei tarvitse ajatella tai opetella piikkinsä käyttöä tai sen käyttötilannetta - kaiken tämän se ymmärtää vaistomaisesti. Tämän vuoksi vaisto on myös väistämättä erikoistunutta (Bergson 2013/1907, 173-174). Pistiäisen vaistomainen tieto piikin käytöstä on täydellistä: vaisto ymmärtää kohteensa täysin, mutta tämä tieto ei ole sovellettavissa mihinkään muuhun (Bergson 2013/1907, 141).

Näihin kahteen tiedon muotoon liittyvä käsitys välineistä havainnollistaa molempien tiedon muotojen luonteita. Äly on tietoa ulkoisista suhteista. Se kykenee yhdistelemään asioita ja näkemään esimerkiksi vaikutus- tai seuraussuhteita ja kykenee siis ennakoimaan ja spekuloimaan. Sen tarvitsee ymmärtää tarkastelunsa kohdetta vain siinä määrin kuin se on suhteessa muihin olioihin. Äly ei siis ole kiinnostunut asioista itsestään. Se on kiinnostunut siitä, kuinka asiat toimivat tai kuinka niitä voidaan hyödyntää. (Bergson 2013/1907, 154.) Tässä mielessä tiede ja sen tapa tarkastella todellisuutta on kuin ihmisälyn luontaista jatkumoa: se analysoi ja yhdistelee, ja se on ennen kaikkea kiinnostunut asioiden välisistä suhteista. Se siis tarkastelee asioita niiden ulkopuolelta, suhteessa toisiin asioihin.

Vaisto on sen sijaan Bergsonin mukaan sisäsyntyistä tietoa: se tavoittaa asioita sisältä käsin. Se ei tarkastele tai ymmärrä asioiden välisiä suhteita, vaan asioita sellaisina kuin ne ovat. Yhtenä esimerkkinä vaiston luonteesta Bergson käyttää sitä, kuinka pistiäinen pistää uhriaan. Kyse on Bergsonin mukaan tietynlaisesta sympatiasta. Ajatuksena näyttää olevan, että pistiäinen pistää uhriaan oikealla tavalla, koska se välittömästi ymmärtää kohdettaan. Pistiäinen ikään kuin myötäelää kohteensa elämää. Tämä ymmärrys ei perustu ulkoiseen havaintoon vaan Bergsonin ilmaisun mukaan näiden keskinäiseen läsnäoloon. (Bergson 2013/1907, 174-175.) Tulkitsen, että kyse on ikään kuin ilmapiiristä ja sen lukemisesta. Ymmärrys vihamielisestä ympäristöstä ei perustu havaintoihin tai reflektioon, vaikka voisimmekin jälkikäteen analysoida, miten kukin paikallaolija käyttäytyi ja toimi tilanteessa ilmapiirin synnyttämiseksi. Pikemminkin koemme sen välittömästi.

Mutta miten äly ja vaisto liittyvät intuitioon? Vaistoon liittyen voidaan Bergsonilta poimia seuraava huomio:

Mutta itse elämän sisään meidät ohjaa intuitio, jolla tarkoitan vaistoa, josta on tullut pyyteetön, itsestään tietoinen ja kykenevä reflektoimaan kohdettaan ja laajentamaan sitä loputtomasti. (Bergson 2013/1907, 178.)^{5}$ 
Vaisto saa tietoa tarkastelunsa kohteesta nimenomaisesti sisältäpäin ja välittömästi, ja sen tieto on tässä suhteessa "absoluuttista". Bergsonin esityksessä se kuitenkin kykenee saavuttamaan tietoa vain rajallisesta määrästä kohteita: vaiston tieto on sisäsyntyistä ja annettua. Äly sen sijaan voi ottaa tarkastelunsa kohteeksi käytännössä mitä tahansa. Vaisto ei myöskään älyn tapaan kykene reflektoimaan tiedon kohdetta ja siten yhdistämään aiempaa siihen tai tarkastelemaan asioiden välisiä suhteita. (Bergson 2013/1907, 141.) Näitä kykyjä Bergson näyttää kuitenkin liittävän intuitioon edeltävässä lainauksessa. Näyttää siis, että intuitiossa on tietyllä tapaa kysymys vaiston ja älyn piirteiden yhdistämisestä. Tällaista ajatusta tukee myös Bergsonin varhainen määritelmä intuitiolle artikkelissa "Introduction à la métaphysique" (Johdatus metafysiikkaan, 1903): "Intuitioksi kutsutaan tätä älyllisen sympatian lajia [...]." (Bergson 1903, 3.) Intuitiossa on siis kyse jollain tavalla älystä ja vaistosta ja näistä jälkimmäisessä erityisesti siihen liittyvästä sympatiasta.

Toisin sanoen, vaikka äly liittyy niin vahvasti tieteeseen, se on myös filosofialle keskeinen. Äly on Bergsonille intuition lähtökohta - intuitio on oikeastaan kytkeytynyt siihen (Bergson 2013/1907, 342). Tämä liittyy nähdäkseni ajatukseen, että intuitioon liittyvät vaiston piirteet ovat ihmisajattelun luonteelle epätyypillisiä - jopa sen luonteen vastaisia. Tämän vuoksi ihminen ei kykene kiinnittymään vaistonkaltaiseen tietoon kuin hetkellisesti, ja tämä vaatii huomattavia ponnisteluja (ks. Bergson 2013/1934, 27). Voimme ajatella älyä ja vaistoa aineen ja hengen tapaan toisilleen vastakkaisina suuntina; ihmiselle vaiston kaltainen ajattelu on kulkemista vastavirtaan. Siksi kaikesta huolimatta äly on intuition perusta älyllisenä sympatiana.

Intuitiossa vaisto tarkoittaa sisäistä kokemusta, sisältä käsin saatua tietoa, jonka avulla ymmärrämme tarkastelun kohdetta itseään (vrt. Bergson 2013/1934, 136-137). Se on aikaisemmin kuvattua muutoksen välitöntä ymmärrystä. Bergsonille filosofian tärkein aines perustuu välittömän kokemuksen antamiin sisältöihin. Filosofiassa ja intuitiossa on kyse prosessista, jossa älymme jäsentää sisäistä kokemustamme yrit- tämällä löytää sille sopivaa kielellistä muotoa. Juuri tässä mielessä se on älyn ja vaiston yhdistelmä: intuitioon näyttää liittyvän sekä tietoinen että tiedostamaton aspekti älyn ja vaiston tapaan. Bergsonin kuvauksen mukaan intuitio on älyn tapaan pääsääntöisesti tietoista (ja itsetietoista), mutta sen kääntyessä välittömään sisäiseen kokemukseen tavoitettu tieto ei ole tietoisesti jäsentynyttä (Bergson 2013/1934, 27-28).

Älyn avulla filosofisia näkemyksiä voidaan kommunikoida ja jäsentää. Kyse on filosofiseen ajatteluun liittyvästä reflektiosta. Äly yhdistelee nykyistä tietoa aiempaan ja mahdollistaa tiedon kartuttamisen. Ilman sitä intuitio jäisi vaistoksi, tiedoksi yksittäisistä kohteista ja kyvyttömäksi arvioimaan asioiden välisiä suhteita (Bergson 2013/1907, 179). Nähdäkseni filosofialle keskeinen tehtävä - asioiden käsitteellistämien - on nimenomaan älyllinen tehtävä. Mutta itse käsittämisen ydin, välittömän kokemuksen tavoittaminen, edellyttää sympatiaa.

Älyn ja vaiston keskinäistä täydentävyyttä luonnehtii hyvin tämä Bergsonin huomautus: "On asioita, joita vain äly kykenee etsimään, mutta joita se itse ei koskaan löydä. Vain vaisto voisi löytää ne, mutta se ei koskaan etsi niitä."7 (Bergson 2013/1907, 152.) Voidaan ehkäpä siis ajatella, että intuitiossa äly kykenee ikään kuin koordinoimaan ja kartoittamaan ajattelua, mutta vasta ei-älyllinen vaistonkaltainen sympatia todella tavoittaa sen, mitä filosofi haluaa ymmärtää.

\section{Intuitio metodologisesta näkökulmasta}

Intuition vertailu ja jäsentäminen älyn ja vaiston kautta näyttää viittaavan siihen, että siinä olisi kyse filosofialle ominaisesta tiedon muodosta. Eteneminen kohti intuitiivista tietoa on hyvin päämäärähakuista ja siihen vaikuttaa liittyvän filosofialle ominainen menetelmä. Seuraavaksi tarkastelen sitä, kuinka Bergson puhuu metodistaan ja miten intuitio näyttää kytkeytyvän siihen.

Vuonna 1916 pitämässään luennossa (Discours prononcé à la résidence des étudiants) Bergson tekee tärkeän huomion filosofisesta menetelmästään. Hän esittää, että filosofian metodin tulisi 
jakautua kahteen vaiheeseen. Ensimmäisessä vaiheessa filosofin tulee Bergsonin mukaan perehtyä tutkittavaa asiaa ympäröivään tieteelliseen keskusteluun. Mikäli olemme kiinnostuneita elämän luonteesta, meidän on perehdyttävä evoluutiobiologiaan. Mikäli kyse on taas tietoisuudesta tai muistista, meidän on perehdyttävä psykologiaan tai neurologiaan. Minkä tahansa aiheen filosofi ottaakaan käsittelyynsä, hänen on otettava tutkimuksensa lähtökohdaksi aiheen kannalta relevantit tieteenalat. (Bergson 1972, 1197.) Tätä periaatetta Bergson itse selvästi noudatti, sillä kaikissa hänen pääteoksissaan esitellään aiheeseen liittyvää tieteellistä tutkimusta. ${ }^{8}$

Tieteellisten tutkimusten merkitys kytkeytyy Bergsonin huomioon siitä, kuinka filosofian tulisi toimia ja edetä todellisuuden omilla ehdoilla. Hänen mukaansa kokemuksen eri piireissä voidaan saada suuntia todellisuuden "mutkaisien ja muuttuvien ääriviivojen" seuraamiseen. Näitä suuntia hän nimittää tosiasialinjoiksi (lignes de fait). (Bergson 1959, 7-8.) Yksikään näistä tosiasialinjoista ei tavoita totuutta, mutta yhdessä ne osoittavat oikean suunnan. Tosiasialinjat eivät koskaan yllä totuuteen asti, mutta niitä voidaan Bergsonin mukaan ikään kuin pidentää. (Bergson 1959, 7-8; Bergson 1990, 263.) Tulkintani mukaan Bergsonille nimenomaan tieteisiin perehtyminen on tätä tosiasialinjojen etsimistä. Riittävällä perehtymisellä saamme useita suuntaviivoja sille, millainen esimerkiksi elämä on luonteeltaan. Mutta lopullinen linjojen pidentäminen ja kurottaminen kohti totuutta on tulkintani mukaan mahdollista vasta intuition avulla.

Konkreettisempi käsitys tosiasialinjojen luonteesta voidaan saada tarkastelemalla yhtä Bergsonin esitystä sellaisesta. Teokseen Henkinen tarmo (L'énergie spirituelle, 1919) sisällytetyssä luennossa "Tajunta ja elämä” Bergson käsittelee tietoisuuden ja elämän välistä suhdetta. Yhtenä keskeisenä kysymyksenä luennolla on, mikä on tietoisuuden tehtävä. Yhdessä tähän liittyvässä tosiasialinjassa Bergson lähtee ajatuksesta, että parhaiten tuntemassamme olennossa, eli meissä itsessämme, tietoisuus toimii aivojen välityksellä. Aivot ovat kuitenkin osa keskushermostoa, johon kuuluu myös esimerkiksi selkäydin. Bergson toteaa, että tiedämme selkäytimeen liittyvän mekanismeja, jotka ovat valmiita suorittamaan erilaisia reaktioita ulkoisiin ärsykkeisiin. Jokin ulkoinen ärsyke voi synnyttää hermoimpulssin, joka suorittaa selkäytimen kautta välittömän reaktion. Mutta joissain tapauksissa impulssi ei mene suoraan selkäytimeen vaan käy aivoissamme ennen kulkeutumista selkäytimeen ja reaktion synnyttämistä. Bergsonin mukaan vaikuttaa siltä, että kiertoteitse kulkiessaan reaktio ulkoiseen ärsykkeeseen ei ole automaattinen vaan valittu. Näiden pohjalta saadaan tietty suunta ja tosiasialinja, jonka mukaan "aivot ovat valinnan elin". (Bergson 1959, 11-12.) Nähdäkseni on vielä syytä huomauttaa, että linja perustuu vaikutelmaan. Linjaa ei muodosteta ainoastaan kokoamalla tosiasioita yhteen vaan siinä on mukana filosofin oma näkemys.

Näiden eri linjojen kokoaminen muodostaa siis filosofisen menetelmän ensimmäisen vaiheen. Toinen vaihe on Bergsonin mukaan "varsinaisesti filosofinen" ja tätä vaihetta hän kutsuu intuitioksi. Toisessa vaiheessa hänen mukaansa "asetutaan sympaattisesti todellisuuden sisään" (Bergson 1972, 1197). Tosiasialinjojen pohjalta tavoitetaan asia itsessään intuition avulla ikään kuin sisältä käsin, ei siis ulkopuolelta tarkastelemalla. Intuition avulla tosiasialinjoja voidaan "pidentää" niin, että saavutamme itse tarkastelun kohteen luonteen. Metodin näkökulmasta tässä on keskeistä se, miten tämä sympaattinen asettuminen tapahtuu.

Aiemmin esitin, että Bergsonille välitön kokemus perustuu kokemukseen omasta kestostamme. Oikeastaan Bergson esittää, ettei ihminen voi saada täydellisen välitöntä tietoa muusta kuin omasta kokemuksestaan, omasta tietoisuudestaan. Ihminen ei voi siten varsinaisesti ymmärtää välittömästi mitään muuta kuin itseään. (Bergson 2013/1934, 40-41.) Mutta tarkoittaako tämä, että filosofiassa voimme ymmärtää vain omaa välitöntä kokemustamme? Onko intuitio yksinkertaisesti osa omien kokemusten tiedostamista, itsereflektiota? Bergson esittää, että intuitiossa ymmärrys omasta sisäisestä kestosta voidaan laajentaa koskemaan myös muiden kestoa sympatian, tietynlaisen myötäelämisen kautta (Bergson 2013/1934, 28). "Sympaattisessa asettumisessa" on siis kyse 
oman keston kokemuksen laajentamisesta.

Mutta Bergson ei jää tässä vain toisiin tietoisiin olentoihin. Hän menee vielä askeleen pidemmälle ja esittää, että intuitio voidaan itse asiassa ulottaa muuhunkin kuin omaan tai toisen ihmisen tietoisuuteen. Hänen mukaansa intuitio on mahdollista ulottaa kaikkeen muuttuvaan. Esimerkiksi filosofia voi tarkastella elämän liikettä, sikäli kuin se on jatkuvaa muutosta ja sillä on kesto (Bergson 2013/1934, 28). Toisin sanoen intuition avulla voidaan ymmärtää todellisuudessa kaikkea muuttuvaa. Sympatia kahden ihmisen tai ihmisen ja toisen eläimen välillä onkin helposti ymmärrettävissä, mutta miten sympatiaa voidaan soveltaa, kun filosofiassa tarkastellaan esimerkiksi elämän luonnetta?

Ymmärtääksemme, miten intuition ulottaminen sympatian kautta mahdollistuu, on aivan ensimmäiseksi aloitettava tietoisuuden käsitteen määritelmästä, sillä välitön kokemus tietoisuudestamme on intuition lähtökohta. Bergsonin mukaan tietoisuutemme, sellaisena kuin sen välittömästi koemme, on kokemustemme jatkumo (Bergson 2013/1907, 1). Siihen kuuluu siis kesto. Bergsonille tietoisuus on kuitenkin ennen kaikkea muistia (Bergson 1959, 8). Muisti mahdollistaa tietoisuutemme jatkuvuuden, sillä jos muistia ei olisi, tietoisuus ikään kuin syntyisi joka hetki uudelleen. Se ei kykenisi perustamaan toimintaansa millekään edeltävälle kokemukselle: "Tajunta siis on aina muistia, menneisyyden säilymistä ja kasautumista nykyisyydessä.” (Bergson 1959,9 .) Bergsonille tietoisuus näyttää siis olevan jossain määrin mielen synonyymi. Jokainen kokemuksemme ja ajatuksemme muuttaa tietoisuuttamme ja "erikoistuu", jolloin meille muodostuu persoona. Tietoisuus, siis mielemme tai persoonamme, on ikään kuin läsnäoleva sisäinen minuutemme, joka muuttuu joka hetki. Se luo itseään jatkuvasti uudelleen ja uudelleen kun uudet kokemukset vaikuttavat siihen. (Bergson 2013/1907, 6-7.)

Filosofinen sympatia eli sisäisen kokemuksen laajentaminen perustuu nähtävästi tietynlaiseen analogiaan, olettamukseen sisäisestä samankaltaisuudesta. Vuonna 1893 pitämällään metafysiikan kurssilla Pariisin Henri-IV:n lukiossa Berg- son luonnehtii metafysiikan lähestymistapaa seuraavasti:

[Todellisuuden] substansseja sisältäpäin tarkasteleva metafysiikka, joka päättelee analogian eikä enää induktion kautta, löytää substansseista jotain meidän omaan tietoisuuteemme tai ainakin omaan toimintaamme verrattavaa. ${ }^{9}$ (Bergson 1992, 438.)

David Lapoujade tulkitsee, että kyse on analogiasta, joka ei perustu ulkoiseen samankaltaisuuteen vaan yhteiseen sisäiseen tekijään (Lapoujade 2010, 59-60). Analogian keskeinen tehtävä on tuoda yhteen kaksi erilaista asiaa, joista vain toisen tunnemme hyvin. Toinen osapuoli on meille jollain tapaa tuntematon ja vieras. Koska ihmisäly on tottunut tarkastelemaan kaikkea kuin liikkumattomana aineena, sille muuttuva todellisuus on vieras. Tämän vuoksi myös ihmisen tietoisuuden luonne itse on sille vieras (Bergson 2013/1934, 41). Tietoisuutemme on meille kuitenkin välittömästi läsnä ja voimme siksi tavoittaa sen luonteen. Voimme siis ymmärtää tietoisuuden kautta muutosta, vaikka ihmisäly ei ole siihen tottunut. Äly kykenee tarkastelemaan muutosta vain pysäyttämällä sen; intuitiossa muutos tavoitetaan sisäisen kokemuksen avulla sellaisenaan. Tavoitamme muutoksen samalla tavalla kuin tavoitamme oman kestomme ja ajallisuutemme. Ymmärrämme muutosta ulkopuolellamme kuin peilaamalla tietoisuutemme luonnetta muuhun todellisuuteen. Jos siis esitämme, kuten Bergson tekee teoksessa L'évolution créatrice, että tietoisuus ja elämä ovat jossain määrin keskenään analogisia, pystymme tarkastelemalla omaa tietoisuuttamme saamaan tietoa elämän luonteesta.

Mutta millä perustein ja missä määrin tätä analogiaa voidaan käyttää? Tuntuisihan järjettömältä vain olettaa, että elämä on kaikin puolin analoginen tietoisuutemme kanssa. Analogian ydin on, että todellisuudessa kaikki, mikä on kestoa ja muutosta, on analogista tietoisuutemme luonteen kanssa. Esimerkiksi luennolla "Tajunta ja elämä" Bergson käsittelee kysymystä, mikä on tietoisuuden tehtävä ja mitkä olennot ovat tietoisia. Tämä johtaa perustavaan kysymykseen, 
miten voidaan tietää toisten ihmisten olevan myös tietoisia. Hänen mukaansa päättelyn lähtökohtana on tietty analogisuuden olettamus:

Teidän ja minun kesken vallitsee ilmeinen ulkonainen samankaltaisuus, ja tämän ulkonaisen samankaltaisuuden nojalla te päättelette sisäistäkin yhtäläisyyttä olevan olemassa. [...] Seuratkaamme siis analogian juonta tutkien mihin saakka tajuisuus ulottuu, missä kohden se taukoaa. (Bergson 1959, 10.)

Samalla tavoin oletamme, että havaitessamme todellisuudessa muutosta kyse on samanlaisesta muutoksesta kuin meissä itsessämme. Tämä perustuu käsitykseen todellisuudesta henkenä ja aineena. Intuitioon liittyvässä sympatiassa on siis kyse siitä, että tavoitamme omassa tietoisuudessamme todellisen liikkeen ja muutoksen, todellisuuden toisen aspektin, hengen. Koska Bergsonille todellisuudessa kaikki muodostuu aineesta ja hengestä, voimme olettaa tämän aspektin olevan myös läsnä tarkastelumme kohteessa sikäli kuin se ilmenee meissä. Tämän olettamuksen perusteella voimme "myötäelää" elämän luonnetta ja ikään kuin kokea sen. Lapoujaden mukaan tällöin tarkastelumme kohde ikään kuin "tulee hengeksi" (Lapoujade 2010, 56). Olettaessamme tarkastelun kohteena olevan muutoksen tietoisuudessamme olevan muutoksen kaltaiseksi me ikään kuin muunnamme sen meille tavoitettavaan muotoon. Mutta samalla oikeastaan voidaan sanoa, että sympatiassa me itse yritämme tulla oman tarkastelumme kohteeksi ja myötäelää tarkastelun kohteemme liikettä.

Pelkällä olettamuksella yhteisestä jaetusta luonteesta emme pääse vielä pitkälle filosofiassa. Metodin ensimmäinen vaihe toimiikin sen pohjana. Käsitystämme tarkasteltavasta asiasta on rakennettava niin pitkälle kuin mahdollista tieteen löydöksien pohjalta. Voimme hyödyntää analogiaa niin pitkälle kuin tieteen asettamat puitteet sen sallivat. Kun olemme saaneet koottua yhteen suuntaviivoja, jotka jo ennakoivat, mitä tulemme löytämään, on viime metrit kurottava umpeen intuitiolla, ajattelemalla tarkastelun kohdetta tietoisuutemme tapaan muuttuvana. Palataan tapaukseen, jossa Bergson halusi selvittää tietoisuuden ja elämän suhdetta ja tarkasteli yhtä tosi- asialinjaa. Mainitun linjan lisäksi Bergson esittää lukuisia muita johteluita liittyen tietoisuuden ja elämän väliseen suhteeseen. Lopulta hän kokoaa yhteen eri johtopäätöksiä, joihin on eri linjoilla päätynyt, ja esittää seuraavaa:

Jos nyt jätämme tämän viimeisen tosiasialinjan ja palaamme edelliseen [...] niin emmekö ala aavistella, että tajunta, kulkiessaan läpi aineen, karaistuu kuin teräs valmistautuen tehokkaamman toiminnan, intensiivisemmän elämän varalle. Minä käsitän tämän viimeksi mainitunkin elämän olevan taistelun elämää, keksimisen vaatimista, luovaa kehitystä [l'évolution créatrice]. (Bergson 1959, 30; suomennosta muutettu.)

Tosiasialinjojen pohjalta löydetään siis suunta. Tarkastelun kohde alkaa saada muotoa, käsityksemme siitä tarkentua. Siirtymää vaikutelmista lopulliseen käsitykseen ei kuitenkaan avata. Bergson vain luonnehtii näkemystään spekulatiiviseksi (Bergson 1959, 31). Nähdäkseni juuri tätä vaihetta filosofin työssä onkin lähes mahdoton kirjata auki. Bergson yksinkertaisesti toteaa, miten asian on käsittänyt. Kuitenkin juuri näihin lainauksen johtopäätöksiin hän päätyy puhtaasti intuition kautta. Ne ovat hyvinkin spekulatiivisia, koska ne ovat tietyllä tapaa olettamuksen varassa muodostettuja täydennyksiä kuvaan, joita tosiasialinjat ovat lähteneet piirtämään.

\section{Menetelmä vai tiedon muoto?}

Bergsonin käsitellessä tieteen ja filosofian välistä työnjakoa intuitio näyttäytyy pikemminkin tiedon muotona, joka tietyllä tavalla eroaa älystä. Myös tarkasteltaessa älyä ja vaistoa intuitio näyttäytyy tiedon muotona, joka on kuin näiden yhdistelmä. Kuitenkin joissakin yhteyksissä näyttää taas siltä, että intuitioon liittyy sympatian kautta jotakin metodologista tai että se on filosofian metodiin liittyvä vaihe. Mitä näistä luonnehdinnoista liittyen metodiin ja filosofiseen tiedon muotoon voidaan päätellä? Onko intuitiossa kyse filosofian metodista vai siitä erotettavissa olevasta tiedon muodosta? Vai kytkeytyvätkö nämä jollakin tavalla yhteen?

Jokseenkin vakuuttavalta tulkinnalta näyttää käsitys, jonka mukaan intuitiossa on kyse ennen 
kaikkea tiedon muodosta. Bergsonin metodissa voidaan nähdä olevan kyse yksinkertaisesti intuitiivisen tiedon saavuttamisen mahdollistamisesta, jossa metodologisinta on sympatia; systemaattinen sisäisen kokemuksen ulottaminen toiseen kohteeseen. Jos kuitenkin vertailemme Bergsonin kuvauksia intuitiosta tietynlaisena tiedon muotona hänen metodologisiin huomioihinsa huomaamme paljon päällekkäisyyttä. Bergsonin metodi, sikäli kuin sen voidaan rekonstruoida, sisältää intuitiivisen tiedon tapaan ajatuksen sympatiasta. Yritykset erottaa intuitiivinen tieto ja filosofian metodi toisistaan näyttävät johtavan varsin keinotekoisiin ratkaisuihin, eivätkä ne näytä tekevän oikeutta Bergsonin filosofialle. Nähdäkseni siis Bergsonin filosofiassa tiedon muoto ja metodi ovat kytkeytyneet yhteen. Oikeastaan voitaisiin sanoa, että metodi ja tiedon muoto ovat vain kaksi eri näkökulmaa filosofiseen prosessiin, jota nimitetään intuitioksi.

Intuitioon liittyy epäilyksettä ainutlaatuinen tiedon muoto ja sille erityinen aines: intuition "empiriaa" on välitön sisäinen kokemus, ja filosofinen tieto perustuu kykyyn huomata ja tavoittaa tämä kokemus. Filosofian tiedon muoto on luonteeltaan absoluuttista, eli Bergsonin näkemyksen mukaan se on tekemisissä suoraan tarkastelun kohteen itsensä kanssa ilman välittäviä tekijöitä. Kun tarkastellaan intuitiota metodologisten huomioiden yhteydessä, se näyttää liittyvän erityisesti tiettyyn metodin vaiheeseen. Bergson esitti intuition olevan filosofisen metodin puhtaasti filosofinen vaihe, joka kytkeytyy tieteen tuloksiin. Tieteiden tarjoaman tiedon pohjalta yritämme intuitiolla ymmärtää itse tarkastelun kohdetta ja päästä tarkastelemaan sitä sisältä käsin. Tämä onnistuu sympatialla, ajattelemalla tarkastelun kohdetta oman tietoisuutemme luonteemme kautta. Tarkastelemme kohdetta kuin se olisi luonteeltaan oman tietoisuutemme kaltainen, kuin se olisi samalla tavalla jatkuva ja muuttuva. Tätä metodologiaa voidaan hahmottaa esimerkin kautta. Teoksessa L'Évolution créatrice Bergson esittää, että mekanistisessa esityksessä elämän luonteesta on pikemminkin kyse menetelmästä kuin opista (Bergson 2013/1907, 346). Mekanistisessa käsityksessä tiivistettynä tarkastellaan elämää kuin se olisi redusoitavissa tiettyihin perustavanlaatuisiin mekanismeihin. Mikäli kyseiset mekanismit tunnetaan riittävän hyvin, voidaan elämän kehityskulku laskelmoida nykytilanteesta käsin. (Bergson 2013/1907, 37.) Sanoessaan, että kyse on pikemminkin metodista kuin opista, Bergson nähdäkseni tarkoittaa, että muutosta tarkastellaan mekanismeina. Sitä tarkastellaan tietystä näkökulmasta tai tietyn mallin mukaisesti. Tässä mielessä myös intuitio voidaan ymmärtää metodina: intuition avulla muutosta tarkastellaan ihmisen tietoisuutta muistuttavana kestona.

Siitä huolimatta, että intuitiota kuvataan sekä tiedon muodoksi että filosofisen metodin vaiheeksi, sen voidaan katsoa olevan jotakin kokonaisvaltaista. Bergsonin esitys filosofiseen metodiin liittyvistä tosiasialinjoista nähdäkseni osoittaa, ettei intuitio ole täysin erillinen metodin ensimmäisestä eli "tieteellisestä" vaiheesta. Kuten aiemmin todettiin, Bergsonin tapa muodostaa ensimmäisessä vaiheessa tosiasialinjoja pohjautuu tieteen antamiin tietoihin esimerkiksi aivojen toiminnasta keskushermostossa. Kuitenkin jokaista linjaa määrittää näkemys, ajatus siitä mihin nämä tosiasiat viittaavat. Bergsonin kuvauksessa nämä indikaatiot näyttävät olevan hänen itsensä esittämiä ja eivätkä vaikuta puhtaan analyyttisiltä. Siksi myös nämä suuntaviivat perustuvat tulkintani mukaan intuitioon. Näkemyksemme siitä, mitä tosiasiat indikoivat ja minkälaisen linjan ne muodostavat, perustuu intuitioon. Se on siis läsnä filosofisen prosessin jokaisessa vaiheessa. Metodin toinen vaihe, jossa kaikki tosiasialinjat on kerätty, on siis vain puhtaasti intuitiivinen. Tämän vuoksi intuitiossa ei ole kyse vain lopputulemasta, tarkasteltavan asian luonteen lopullisesta ymmärtämisestä. Se toteutuu sekä filosofin työtä ohjaavana näkemyksenä, että viimekätisenä oivalluksena.

Filosofinen prosessi itse asiassa muistuttaa tietoisuuden luonnetta sellaisena kuin Bergson sitä kuvaa. Kaikkien tieteiden antamien tietojen pohjalta muodostamme käsityksemme uudelleen intuition avulla: saamme ajattelulle uuden suunnan. Lopulta, kun olemme löytäneet riittävästi suuntia käsityksellemme, saamme viimein kokonaiskuvan tarkastelun kohteesta ja käsitämme, miten aiemmat käsi- 
tyksemme sopivat yhteen. Kun intuitiota ajatellaan tällaisena prosessina, nähdään mitä Bergson tarkoittaa sanoessaan intuition olevan filosofinen metodi. Se on käsityksemme jatkuvaa uudelleen luomista pohjaten niihin tosiseikkoihin, jotka tieteellä on tarjottavanaan, siten että ne myötäeletään suhteessa oman tietoisuutemme luonteeseen. Näin välitön ymmärryksemme omasta tietoisuudestamme ulotetaan sille ulkoisiin kohteisiin. Tiedon muotoa ja metodia ei voida suoranaisesti erottaa toisistaan, sillä metodissa näyttää käytännössä olevan kyse todellisuuden tarkastelusta tässä määrätyssä tiedon muodossa. Jos viemme ajatusta vielä askeleen pidemmälle, näyttää siltä, että Bergsonin ajatukset intuitiosta näyttävät implikoivan, että filosofia ja sen tekeminen on tietynlaista luomista. Muutoksen tarkastelu muutoksena on itse ajattelun luomista.

\section{Johtopäätökset}

Näyttää siis siltä, että vaihtelevat tulkinnat Bergsonin intuition roolista kumpuavat siitä seikasta, että intuitiolla on Bergsonin ajattelussa kaksoisrooli. Intuitio on Bergsonille samalla sekä filosofinen tiedon muoto että filosofinen metodi. Sikäli kuin intuitio on välitöntä ymmärrystä ja tietoa asioista sisältä käsin, se on ainutlaatuinen tiedon muoto. Filosofinen metodi se on taas sikäli, että siinä todellisuutta tarkastellaan sisältä käsin meidän tietoisuutemme luonteeseen pohjaavan analogian kautta ikään kuin tuoden todellisuuden tähän intuition tavoittamaan muotoon. Ja tämä tapahtuu tarkastelemalla todellisuutta ajallisuuden näkökulmasta.

Bergsonin haasteena on vastata filosofialle asettamiinsa vaatimuksiin, eli pyrkimykseen pois käsitejärjestelmistä, joissa käsitteet alkavat määrittää käsitystämme enemmän kuin tosiasiat. Bergsonin intuitiokäsitys nimittäin kytkeytyy vahvasti hänen dualistiseen käsitykseensä hengestä ja aineesta ja edellyttää jossain määrin näiden käsitysten hyväksymistä. Tämän vuoksi Bergsonin intuition käsitettä ei voi vain yksinkertaisesti ottaa ja soveltaa; sen mukana tulee väistämättä varsin laaja filosofinen järjestelmä.

Kuitenkin Bergsonin tulkinta on nähdäkse- ni kiinnostava ja relevantti vaikka näihin lähtökohtiin ei sitoutuisikaan. Bergson ajattelijana, joka ottaa intuition filosofian keskiöön tarjoaa myös nykyfilosofialle uuden tavan ajatella intuition roolia. Erityisesti analyyttisessä filosofiassa on käyty viimeisen yli 30 vuoden aikana laajaa keskustelua, ovatko intuitiot luotettava evidenssin lähde. ${ }^{10}$ Suhteessa tähän asetelmaan Bergsonin käsitys tarjoaa uuden varsin poikkeavan tavan tarkastella intuition roolia; intuitiosta tulee pikemminkin filosofista ajattelua ohjaava ja jäsentävä metodologinen tekijä, ja evidenssinä taas toimivat tutkimuskohteen kannalta relevanttien tieteenalojen tutkimustulokset. Intuitiosta tulee evidenssin tai evidenssin lähteen sijaan ajattelua ohjaava menetelmä ja filosofisen tiedon muoto.

Bergsonin ajatus intuitiosta on myös hedelmällinen filosofian menetelmien näkökulmasta. Se tarjoaa yhden näkökulman, joka huomioi filosofisen tiedon luonteen ainutlaatuisuuden ja sisällyttää sen itse menetelmään. Filosofiaan katsotaan usein liittyvän tietty vaihe tai jäsentymätön välittömän käsittämisen hetki, jota ei voida suoranaisesti formalisoida tai kommunikoida. Bergson tarjoaa yhden tavan systematisoida tämän ajatuksen ja myös selvittää, mihin ajattelumme tässä pohjaa: välittömään sisäiseen kokemukseen. Lopullisessa filosofisessa oivalluksessa tavoitamme tai jopa näemme selkeänä sen ajatuksen, johon tosiasialinjat aluksi vain viittasivat.

YTM KATARIINA LIPSANEN on filosofian väitöskirjatutkija Jyväskylän yliopiston Humanistis-yhteiskuntatieteellisessä tiedekunnassa.

\section{VIITTEET}

1 Deleuzen esitys on saanut kovaa kritiikkiä Bergsontutkijoilta (ks. esim Riquier 2009, 133-134). Tunnetusti Deleuzen luennan ei ole edes tarkoitus olla Bergsonin ajattelulle uskollinen (Deleuze 2003/1990, 15). Deleuze tekee kuitenkin tärkeitä huomiota ja nostoja liittyen Bergsonin yleisiin lähestymistapohin ja esimerkiksi filosofian klassisten kysymysten käsittelyyn, jotka ovat varteenotettavia sinänsä, vaikka eivät juuri kytkeydy intuitioon.

2 Ks. Spinoza 1994/1677, 288. 
3 Bergsonin ajatus perustuu lähtökohtaisesti siihen, että filosofian perinteinen käsitys lähtee vääristymästä, joka perustuu huomioon havaittavan todellisuuden muuttuvuudesta. Muuttuvuus liitetään aineeseen ja ikään kuin negaation kautta ideoista tai muodoista tulee ikuisia.

4 Bergsonille muisti on oma keskeinen käsitteensä erityisesti teoksessa Matière et mémoire (Aine ja muisti, 1896). Tässä artikkelissa en käsittele sitä kuitenkaan syvällisemmin. Tässä yhteydessä muisti voidaan ymmärtää melko arkisessa mielessä tekijänä, jonka avulla menneet tapahtumat ovat läsnä nykyisyydessä. Hyvä yleisesitys käsitteestä löytyy esimerkiksi Frédéric Wormsin teoksesta Vocabulaire de Bergson (Worms 2000, 43).

5 "Mais c'est à l'intérieur même de la vie que nous conduirait l'intuition, je veux dire l'instinct devenu désintéressé, conscient de lui-même, capable de réfléchir sur son objet et de l'élargir indéfiniment."

6 "On appelle intuition cette espèce de sympathie intellectuelle [...]."

7 "Il y a des choses que l'intelligence seule est capable de chercher, mais que, par elle-même, elle ne trouvera jamais. Ces choses, l'instinct seul les trouverait; mais il ne les cherchera jamais.”

8 Bergsonin hyödyntämä tieteellisen tutkimuksen määrä on varsin laaja ja peräisin useilta eri aloilta. Esimerkiksi Bergsonin esikoisteos Essai sur les données immediates de la conscience kytkeytyy useiden eri alojen tutkimuksiin. Pelkästään teoksen ensimmäisessä luvussa käsitellessään havaintoa ja välitöntä kokemusta Bergson viittaa muun muassa fysiologi Charles Richet'en, biologi Charles Darwiniin, Charles Frérén psykologisiin tutkimuksiin, useisiin eri psykofysiikan tutkimuksiin, Ogden Roodin fysiikkaan ja väriteoriaan sekä fyysikko Hermann von Helmholtz optiikkaan (Bergson 2013/1889).

9 "[...] la métaphysique qui, étudiant ces substances $d u$ dedans, raisonnant par analogie et non plus par induction y trouve quelque chose de comparable à notre propre conscience et en tout cas à notre propre activité."

10 Tätä keskustelua on hyvin koonnut ja problematisoinut esimerkiksi Julia Langkau (2019).

\section{KIRJALLISUUS}

Bergson, Henri (1903) "Introduction à la métaphysique". Revue de la métaphysique et morale 11, 1-36.

Bergson, Henri (1959/1919) Henkinen tarmo. Suom. Juho August Hollo. WSOY, Porvoo

Bergson, Henri (1972) Mélanges. Presses Universitaires de France, Pariisi.

Bergson, Henri (1990/1932) Les deux sources de la morale et de la religion. Presses Universitaires de France, Pariisi.

Bergson, Henri (1992) Cours, 2: Leçons d'esthétique à Clermont-Ferrand; Leçons de morale, psychologie et métaphysique au lycée Henri-IV. Presses Universitaires de France, Pariisi.

Bergson, Henri (2002/1902) "Cours de Bergson au College de France: histoire de l'idée de temps". Teoksessa Frédéric Worms (toim.) Annales bergsoniennes I: Bergson dans le siècle. Presses Universitaires de France, Pariisi, 25-68.

Bergson, Henri (2013/1889) Essai sur les données immédiates de la conscience. Toim. Frédéric Worms. Presses Universitaires de France, Pariisi.

Bergson, Henri (2013/1907) L'évolution créatrice. Toim. Frédéric Worms. Presses Universitaires de France, Pariisi.

Bergson, Henri (2013/1934) La pensée et le mouvant: essais et conférences. Toim. Frédéric Worms. Presses Universitaires de France, Pariisi.

Arnaud Bouaniche, Arnaud François, Frédéric Fruteau de Laclos, Stéphane Madelrieux, Claire Marin ja Ghislain Waterlot (2013) "Dossier critique". Teoksessa Bergson 2013/1934, 295-612.

Bréhier, Émile (1973) The History of Philosophy, VII: Contemporary Philosophy - Since 1850. Käänt. Wade Baskin. The University of Chicago Press, Chicago.

Chevalier, Jacques (1928) Henri Bergson. Käänt. Lilian Ada Clare. Rider \& Co, Lontoo.

Copleston, Frederick (1994) A History of Philosophy, 9: Maine de Biran to Sartre, Part I: The Revolution to Henri Bergson. Image Book, New York.

Deleuze, Gilles (2003/1990) Pourparles 1972-1990. Les Éditions de Minuit, Pariisi.

Deleuze, Gilles (2011/1966) Le bergsonisme. Pressess Universitaires de France, Pariisi.

Deleuze, Gilles (2018/1966) Bergsonismi. Suom. Eetu Viren. Tutkijaliitto, Helsinki.

François, Arnaud (toim.) (2010) L'Évolution créatrice de Bergson. Vrin, Pariisi. 
Hude, Henry (2008) "Intuition et invention chez Bergson". Teoksessa Anne Fagot-Largeault ja Frédéric Worms (toim.) Annales bergsoniennes, IV: L'Évolution créatrice 1907-2007: épistémologie et métaphysique. Presses Universitaires de France, Pariisi, 179-200.

Langkau, Julia (2019) "Metaphilosophy and the Role of Intuitions". Topoi, 38, 781-789.

Lapoujade, David (2010) Puissances du temps: versions de Bergson. Éditions de Minuit, Pariisi.

Lapoujade, David (2008) "Intuition et sympathie chez Bergson”. Eidos, 9, 10-31.

Riquier, Camille (2009) Archéologie de Bergson: temps et métaphysique. Presses Universitaires de France, Pariisi.

Spinoza, Baruch (1994/1677) Etiikka. Suom. Vesa Oittinnen. Gaudeamus, Helsinki.
Tellier, Dimitri (2008) "Telle est ma vie intérieure, telle est aussi la vie en général". Teoksessa Anne Fagot-Largeault ja Frédéric Worms (toim.) Annales bergsoniennes, IV: L'Évolution créatrice 1907-2007: épistémologie et métaphysique. Presses Universitaires de France, Pariisi, 423-432.

Tellier, Dimitri (2012) La métaphysique bergsonienne de l'intériorité: se créer ou se perdre, Harmattan, Pariisi.

Verdeau, Patricia (2007) "Sur la relation de Bergson à Spencer". Teoksessa Frédéric Worms (toim.) Annales bergsoniennes, III: Bergson et la science. Presses Universitaires de France, Pariisi, 361-376.

Worms, Frédéric (2000) Vocabulaire de Bergson. Ellipses, Pariisi. 